\title{
Questions for Improving the Quality of Machine - Building Enterprises Workforce Management in Post - Crisis Conditions
}

\author{
Lyudmila M. Putyatina, Gennady V. Tikhonov, Lyudmila A. Lavrova, \\ Natalia V. Arsenyeva \\ Moscow Aviation Institute (MAI), Volokolamskoe Highway 4, 125993, Moscow, Russia
}

\begin{abstract}
The article is dedicated to problems that include improving the quality of machine-building enterprises workforce management in post-crisis terms.

There are the main specialties of crisis conditions in economy, which have to be taken into consideration while developing policy in enterprise's staff sphere.

Actuality and novelty of the problem are in extension of the existing crisis, while studying its consequences we just need to analyze and summarize them by encompassing both theory and practice.

The goal of research is finding out possible ways of recovering enterprises' activity, while going out of the crisis on the basis of all resources mobilization and especially labor ones.

The methodological basis of research is fundamental works in enterprises' staff management and possibility of usage in modern conditions.

The indicators, which define the improving of machine-building enterprises workforce management for defining the weakest places in making perspective routes of work with staff in post-crisis conditions, are considered in detail. Such routes as changing average headcount of industry production staff within the enterprise (IPS) and workers, recovering and improving staff structure, usage of work time, estimation of staff movement, estimation of staff quality, question of labor increasing growth, as an important economical criterion of their usage for
\end{abstract}

DOI: 10.18421/TEM94-29

https://doi.org/10.18421/TEM94-29

Corresponding author: Stanka Hadzhikoleva, Moscow Aviation Institute (MAl), Moscow, Russia.

Email: gennadytikhonov@mail.ru

Received: 21 August 2020.

Revised: 15 October 2020.

Accepted: 22 October 2020.

Published: 27 November 2020.

(cc)BY-NC-ND (C) 2020 Gennady V. Tikhonov et al; published by UIKTEN. This work is licensed under the Creative Commons Attribution-NonCommercial-NoDerivs 4.0 License.

The article is published with Open Access at www.temjournal.com enterprises' recovering to the before-crisis development level are studied.

Keywords - crisis problems within enterprises; labor resources; industry production staff; staff categories; staff structures; motivation; training and retraining.

\section{Introduction}

Modern crisis conditions in economy and production allow formulating distinctive sign of current crisis:

- synchronicity of crisis coverage of almost all production industries and enterprises;

- rapidness of diseasing on most enterprises: large, middle and small;

- sharp decreasing of money flow in the production and circulation spheres;

- sharp falling of demand on enterprises' production, etc.

Despite a row of anti-crisis measures, which are taken on the level of Russian Federation Government, way out of the crisis will be rather long and painful for economy, industry and enterprises [1].

In connection with existing conditions, the way out of the crisis will be:

- gradual, demanding adaptation to existing conditions, recovering rhythmic of resources' supply, semi finished products, completing products in consideration with the existing enterprises' specialization;

- long lasting, based on re-watching production program of every enterprise in the basis of large scale diversification of production, in consideration with industry's demands and counties and regions population;

- costly, connected with economies connections recovering, fixing production processes, necessity in compensation for workers of needed downtime, stopping realization of perspective innovative projects, etc. 
However, modern machine-building enterprises nowadays have not only bigtechnological production base, but also qualified staff, which firstly defines possibilities and realization of plans about going out of the crisis, and strategic plans of innovative development and recovering of country's industry in the future [2].

Effective management of labor resources with regard to considered enterprises in post-crisis conditions has to promote to rather fast recovering of enterprises' production power, and also to provide rather quick return to the basic main production activity of before-crisis period with a special responsibility for solving perspective tasks in the future [3].

\section{Materials and Methods}

During the analysis of effectiveness in using labor resources of machine-building enterprises in modern conditions it is logical to use the following directions [2]:

1) middle by year number of workers of IPS and workers, and also changing this number in the last period of time;

2) structural analysis of enterprise's staff in the whole, and also IPS and workers, taking into account its changing and recovery during the last period;

3) effectiveness of using work time and possibility of its increasing;

4) enterprise's staff movement during the needed downtime on the basis of objective and subjective factors;

5) separating staff by professions and qualification, according to the necessity of recovering enterprises' activity;

6) opportunities for growth in labor productivity, taking into account individual factors.

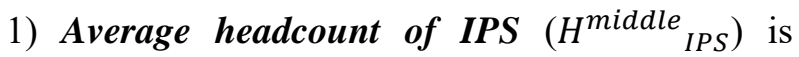
defined in connection with changing of this indicator, during the period of needed downtime through accepting and firing workers:

$$
H_{I P S_{i}}^{\text {middle }}=\frac{\sum_{i=1}^{A_{c a l} H_{I P S_{i}} \times A_{i}}}{A_{c a l}}(\text { people), }
$$

where $H_{I P S}$ is the payroll of IPS in i-period (people); $A_{i}$ is the amount of days in plan period, during which the number of workers was saved;

$A_{\text {cal }}$ is the amount of calendar days in plan period. By the same method we can define average headcount of staff through considered period of time.

An important moment in analysis of this indicator changes is a level of material supply for enterprise workers, during the needed absenteeism on work, with the goal of keeping enterprise's staff for recovering its effective work [4].

Recovered (real) average headcount of staff is counted analogically to IPS headcount in the same period.

Changing the staff's policy within enterprises logically brings in priority attraction of highqualified staff and young specialists, with the goal of their preparation to solving strategic tasks of recovering and development of the enterprise in accelerated timescale [2].

2) Structural analysis of enterprise's staff in whole, and also IPS and workers is based on 100\% connection between their different categories. An important factor of the most optimal staff structure is a rational connection between them, basing on the quality completing of the existing enterprise's tasks. The most rational connection can be:

- overrun of the specific weight of the basic workers above other categories of IPS, because this staff category is immediately taken in realization comprising the production enterprise program and sequence exit from the crisis;

- decreasing of the specific weight of additive workers, while using modern tools of mechanization in serving equipment in the technological processes;

- optimization of engineer technological workers (ETW) headcount, taking into consideration necessity in solving operating and perspective enterprise's development tasks;

- reducing enterprise's managing staff on the basis of digital economy's modern tools and using modern computer programs, which allows optimizing production processes and take reasonable perspective managing decisions.

3) Effectiveness of using work time is defined on the basis of its coefficient, for which weuse the following:

- calendar fund of work time $\left(F_{c a l}\right)$;

- nominal fund $\left(F_{n o m}\right)$ :

$$
F_{\text {nom }}=F_{\text {cal }}-F_{\text {holiday }}-F_{\text {weekend }},
$$

where $F_{\text {holdiay }}, F_{\text {weekend }}$ are holidays and weekends, accordingly, in considered period (days).

- effective fund of work time of the enterprise $\left(F_{\text {eff }}\right)$ :

$$
F_{\text {eff }}=F_{\text {nom }} \times H_{\text {middle }}^{\text {mis }}-N_{n / h} \text { (days), }
$$

where $N_{n / h}$ is the amount ofman-days of enterprise's workers absence on the work for different reasons (days off, illnesses and other regardful reasons).

Seeking coefficient of use of working time on the enterprise $\left(C_{w t}\right)$, is defined: 


$$
C_{w t}=\frac{F_{\text {eff }}}{F_{n o m} \times H^{\text {middle }} \text { IPS }}
$$

Tendency of this indicator growth in time defines a high level of enterprise workers social protection and perspective growth of labor production, which is more important in the period of going out of the crisis and needed downtime.

4) Enterprise's staff movement during the year (especially during recent months) in the basis of objective and subjective firing factors and recruitment can be characterized by the following indicators:

- coefficient of recruitmentofworkers $\left(C_{a w}\right)$ :

$$
C_{\text {aw }}=\frac{H_{\text {recr }}}{H^{\text {middle }}{ }_{I P S}},
$$

where $H_{\text {recr }}$ is the amount of recruitment (people).

- coefficient of workers outputting $\left(C_{\text {out }}\right)$ :

$$
C_{\text {out }}=\frac{H_{\text {fired }}}{H^{\text {middle }} \text { IPS }}
$$

where $H_{\text {fired }}$ is the amount of fired workers (people).

- coefficient of turnover $\left(C_{\text {turnover }}\right)$ :

$$
C_{\text {turnover }}=\frac{H_{\text {fired }}^{\text {wish }}}{H^{\text {middle }}{ }_{I P S}},
$$

where $H_{\text {fired }}^{\text {wish }}$ is the amount of fired workers (at one's wish) (people).

The question about the most perfect tendency turnover indicator is rather a discussion one. On the one hand, it is important to at least about save the staff, which has a rather big work experience on the enterprise, especially on modern conditions [5], [6].

On the other hand, modern process preparation of young and perspective people for developing enterprises demands more considerate analysis to the turnover, which can reflect rather perspective tendencies to increasing effectiveness of using updated staff by the best way to solve tasks of innovative enterprises' development in perspective.

5) Quality content of enterprises' staff in certain degree is defined by:

- amount of ETW and workers, who have gone through additional education and have increased qualification in considered period of time;

- degree of accordance of ETW qualification level of hardness of made constructive, technological and management works;

- degree of accordance of running workers' qualification level of hardness in technological operations and made works.

Regular arrangements for enterprise's workers qualification increasing are the most important regarding the innovative production development perspective after recovering of its plan activity [7].
Level of increasing staff qualification by enterprise $\left(L_{i . q}\right)$ is defined:

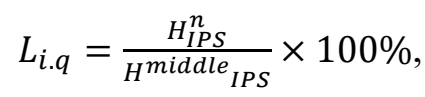

where $H_{I P S}^{n}$ is the headcount of people, working on the enterprise, who have increased the level of their qualification according to increasing category (rank) in summary year (people).

For example, in running year there was increased the rank of 40 workers from 200 people of average headcount and 10 people of 100 of IPS of 100 people increased the category on the enterprise. The level of staff qualification increasing on the enterprise was $16.7 \%$. Thus, for workers this level was $20 \%$ and for other categories of IPS it was 10\%. (Level of workers qualification increasing and other categories of IPS in enterprise's substructures are defined analogically, as on the enterprise in whole).

Accordance of enterprise's staff qualification level of tasks and works hardness can be estimated by the following indicators:

- level of hardness of made and perspective works ( $L_{\text {work hardness }}^{\text {middle }}$;

- level of hardness of workers' qualification, $\left(L_{\text {qual }}^{\text {middle }}\right)$, which are counted:

$$
L_{\text {work hardness }}^{\text {middle }}=\frac{\sum_{i=1}^{k} L_{\text {work hardness }_{i}} \times W_{i}}{\sum_{i=1}^{k} W_{i}},
$$

where $L_{\text {work hardness }}$ is the level of hardness of iwork (development) in current enterprise's work plan;

$W_{i}$ is the specific weight of i-type of works, made by the enterprise in the current period;

$k$ is the number of types of works (developments), realized by the enterprise in current period.

If in the enterprise all plan works are made, $\sum_{i=1}^{k} W_{i}$. Level of hardness of made works is defined by special and accepted on the enterprise scale.

$$
L_{\text {qual }}^{\text {middle }}=\frac{\sum_{i=1}^{k} L_{\text {qual }} \times H_{E T W_{i}}}{\sum_{i=1}^{k} H_{E T W_{i}}},
$$

where $L_{\text {qual }}$ is the worker's qualification level, which makes i-type of works;

$H_{E T W_{i}}$ is ETW headcount, which makes i-type of works (people).

If the hardness level of made works in one year is higher than the according staff qualification level, i.e. $L_{\text {work hardness }}^{\text {middle }}>L_{\text {qual }}^{\text {middle }}$, there is a possibility of lowering the made constructive(technological) developments.

If the hardness level of made works is lower or rather lower of qualification level, i.e., 
$L_{\text {work hardness }}^{\text {middle }}<L_{\text {qual }}^{\text {middle }}$, ETW is not used in full speed, and made works have higher costs.

If the meanings of these indicators will be equal $\left(L_{\text {work hardness }}^{\text {middle }} \cong L_{\text {qual }}^{\text {middle }}\right)$, than this is the most preferable situation, which indicates that IPS on the enterprise is used rather effectively.

For example, IPS on the enterprise makes 5 types of scientifically-technical development with according level of hardness, estimated by 5 point scale ( 5 is the hardest level). The number of IPS, who makes these works, is 100 people. Middle level of IPS qualification of people with different types of works in this case is also estimated by 5 point scale.

If middle weighed hardness level of made IPS in one year ( $\left.L_{\text {work hardness }}^{\text {midde }}\right)$ was estimated in 4 points, and middle weighed IPS qualification level ( $L_{\text {qual }}^{\text {middle }}$ ), which make these works on the enterprises calculated value 3.54 , than in quality making of works this means that staff qualification level on the enterprise is artificially lowered.

For estimation the accordance of hardness level of workers' qualification with regard to made works we compare two calculated indicators:

1) middle tariff categories of works $\left(\gamma_{c}^{\text {middle }}\right)$ :

$$
\gamma_{c}^{\text {middle }}=\frac{\sum_{j=1}^{l} \gamma_{c_{j}} \times V_{j}}{\sum_{j=1}^{l V_{j}} V_{j}},
$$

where $\gamma_{c_{j}}$ is the tariff category, which is necessary for completing j-thtype of work;

$V_{j}$ is the volume of $\mathrm{j}$-thtype of works in current period (in specific gravity or in labor intensity);

$l$ is the amount of types of works, made on the enterprise in current period.

2) middle tariff categories of workers $\left(\gamma_{\text {workers }}^{\text {middle }}\right)$ :

$$
\gamma_{\text {workers }}^{\text {middle }}=\frac{\sum_{i=1}^{q} \gamma_{\text {workers }_{i}} \times H_{\text {workers }_{i}}}{\sum_{i=1}^{q} H_{\text {workers }_{i}}},
$$

where $\gamma_{\text {workers }_{i}}$ is the tariff category of i-worker in current period;

$H_{\text {workers }_{i}}$ is the headcount of workers of i-tariff category in current period (people);

$q$ is amount of tariff categories of workers, used on the enterprise in current period.

In case of excessing the middle tariff category of works hardness degree in comparison with middle tariff workers' qualification, i.e. $\gamma_{\text {workers }}^{\text {middle }}>\gamma_{c}^{\text {middle }}$, this may affect the quality of operations performed.

Another situationis possible: when the middle tariff workers' qualification is higher than the middle tariff works' category, i.e. $\gamma_{\text {workers }}^{\text {middle }}<\gamma_{c}^{\text {middle }}$. In this case, real cost of works and production in the whole will be made higher.
In near equality of these indicators, i.e. $\gamma_{\text {workers }}^{\text {middle }} \cong$ $\gamma_{c}^{\text {middle }}$, we can confidently state about the effective process of organizing production and the rational placement of staff.

For example on the enterprise (shop) there are 8 types of production $(1 \div 8)$, which accords to middle tariff category of works 4.5 , and middle real tariff workers' qualification is 4.85 .

This means that middle level of workers qualification is $7.7 \%$ higher than hardness level of made works, which artificially increases self-cost of made production on the enterprise.

However it is necessary to notice that full accordance of these indicators neither by IPS, nor by workers in real practice cannot be reached, but in these relations there are set up of certain reserves that increasing the effectiveness of using main categories of enterprise's workers and they demand a special analysis.

6) Development and possibilities of its growth on the enterprise. Labor productivity in economy in any enterprise has a significant role in estimation the enterprise's staff management quality. This problem really grows in post-crisis conditions because it speeds up plan works for recovering all production processes [8].

For its increasing different events are used:

- using modern quick equipment;

- improving production organization;

- improving labor conditions;

- increasing qualification and creative initiative of workers on the basis of rationalizing suggestions;

- using outer conjunctive factors, allowing them to optimize cost policy of the enterprise by lowering the products self-cost, etc.

The main factors of development growth, in which there are certain reserves of its increasing on enterprises are: improving materially technical base of production with its sequent innovative update; increasing the management quality and production organization with goals and tasks of enterprises' strategic development growth with regard to amount and quality of made production and sequent increasing of its competitiveness, changing the product policy structure in the enterprise, according to corrected interests of market conjecture and increasing the level of cooperation and production diversification, set up for speeding up the technical economical adaptation to new tasks of industry meaning and population [9].

\section{Literature Review}

In national economy, the development of labor resources is one of the priority directions of government socially economic policy and their 
condition is defined by its different measures. For the first time the term of using a man in labor activity was given by K. Marks: "Under workforce or the power to labor we understand aggregate of physical and spiritual abilities, which have an organism, alive person, and which are used by him whenever he produces any use values" [10].

Social, context human and labor resources characterize the condition of not only economic sphere, but also the whole humanity. In theories of "post-industrial" society of D. Bell [11] the human factor started to be considered in modern understanding of the concept, however its meaning does not come to only economy. Qualified transformations of the "third wave" society are connected also with human qualified transformation, which is becoming the main moving economy force and, at the same time it is changing the way of life and social activity. Before the statement of this question we may notice in the works of German sociologist M. Weber [12], who predicted social crisis of capitalistic (industrial) society, connected with impossibility to reach the value unity and competition of ideologies. Ideas of D. Bell, mentioned in works "The end of ideology" [11] and "Cultural contradiction of capitalism" [12], are mostly an attempt to answer all the questions that were set up by M. Weber.

\section{Research Results}

Among main directions for increasing the labor resources managing effectiveness of machinebuilding enterprises in post-crisis conditions can be surely named including the following ones:

- providing real material support to all workers who has been in needed isolation during the according period of time;

- development of enterprises' activity recovery plan for reaching before-crisis level based on creative initiative of all workers categories;

- making conclusions of crisis impact on financial condition of the enterprise, numeral and qualification of staff;

- making additional staff hiring, based on enterprise's requirement for solving current and perspective tasks;

- recovery the practice for making regular attestations and re-attestations of all staff categories in order to provide professional growth, and also completing staff reserve;

- strengthening the system of labor resources motivation: material, social, etc. based on the key performance indicators of the enterprise, especially during the transition to regular planned work [13], [14];
- system's improvement of selection including the candidates for employment, while it is possible to observe the effective usage of staff in accordance with their qualification;

- making a decision, in a planned manner, to educate and re-educate all workers categories to study new and the most perspective types of work, especially in terms of needed production diversification;

- stimulating the system of corporative communications, increasing the effect of work contacts in established conditions;

- attracting graduates of specialized universities and other educational institutions for solving promising enterprise development projects;

- workers education, using the program of staff development and management competitions;

- development of rotation and vertical migration of staff;

- strengthening social policy (development and financing of social programs for children of workers; conduct sports and recreation activities for employees of the enterprise and their families; provision of food, etc.) for the full restoration of all social-economic aspects of the life within enterprises, etc [15], [16].

\section{Discussion}

As a consequence of the exclusivity on the existing crisis in industry and in the country, the methods of overcoming it and restoring the regular work of enterprises and industry of the country in the whole, are quite controversial because of a number of reasons:

- crisis depth, which different enterprises have and even industries to a certain degree is something different;

- each enterprise just has to estimate a real damage in financial relation and in future staff providing;

- real innovative projects will be stopped to a certain degree, because of limitation or lack of their financing;

- enterprises will possibly have to diversify its production activity with changed industry's requirements and necessity of completing consumers market orders;

- terms of leading enterprises on before-crisis level are rather hard to end estimated today. However for qualification and creative staff initiative on the enterprise there are plan preliminary counts for changing production program and requirements in different staff categories. 


\section{Conclusions}

Modern crisis conditions in economy and production allow formulating distinctive signs of current crisis: synchronization of crisis coverage in almost all spheres of production and enterprises; speed of spreading; sharp reducing of cash flow in production and circulationspheres; sharp demand reducing on enterprises' production, etc.

Despite a row of anti-crisis character measures, which are accepted on the Russian Federation Government level, way out of the crisis will be rather long and painful for economy, industry, production and enterprises.

Effective labor resources management of considered enterprises in post-crisis conditions has to produce rather quick enterprises' production power recovery, and also to provide rather quick return to the main production activity of before-crisis period with special responsibility for solving perspective tasks in the future.

Analysis of the effectiveness on labor resources management is determined by the following areas: changes in the average number of industrial staff in general and especially workers' rationality of the staff structure; usage of working time movement of frames; professional and qualification composition of staff corresponding to the specialization of the enterprise, as well as the real growth of output.

Among the main directions for increasing the effectiveness of labor resources management of machine-building enterprises in post-crisis conditions the following can be certainly emphasized:

- providing real material support to all workers who has been in needed isolation during the according period of time;

- development of enterprises' activity recovery plan for reaching the before-crisis level on the basis of creative initiative of all workers categories;

- making conclusions on crisis impact with regard to financial condition of the enterprise, numeral and qualification of staff;

- making additional staff hiring, based on enterprise's requirement for solving current and perspective tasks;

- recovery of practice of making regular attestations and re-attestations of all staff categories for providing professional growth, and also completing staff reserve;

- strengthening the system of labor resources motivation: material, social, etc., which are based on the key performance indicators of the enterprise, especially during the transition to regular planned work;

- system's improvement of selection of candidates for employment, while it is possible to observe the effective usage of staff in accordance with their qualification.

It is necessary to mention that plan work for increasing the effectiveness and quality of enterprises' staff management increasing is a key to recovery of their plan activity and solving strategic tasks of development in the future [17], [18].

\section{References}

[1].Gorbunova, O. N. (2013). Gladysheva AV Klyuchevye osobennosti formirovaniya trudovogo resursa $\mathrm{V}$ informatsionnom obshchestve [Key features of formation of a labor resource in information society]. Sotsial'no-ekonomicheskiye yavleniya i protsessy, (9), 27-31.

[2].Putyatina, L. M., \& Arsen'yeva, N. V. (2020). Innovatsionnyy potentsial mashinostroitel'nogo predpriyatiya i metodika yego otsenki. Voprosy innovatsionnoy ekonomiki, 10(1), 563-572.

[3].Putyatina, L. M., \& Arsen'yeva, N. V. (2020). Razvitiye trudovogo potentsiala kak element strategii upravleniya mashinostroitel'nym predpriyatiyem. Ekonomika truda, 7(2), 183-192.

[4].Komarova, N. V., Zamkovoi, A. A., \& Novikov, S. V. (2019). The Fourth Industrial Revolution and Staff Development Strategy in Manufacturing. Russian Engineering Research, 39(4), 330-333.

[5].Yashin, A. (2011). Razrabotka kadrovoy strategii innovatsionnogo predpriyatiya. Kadrovik, (10), 131135.

[6].Zamkovoi, A. A., Komarova, N. V., \& Novikov, S. V. (2019). Rethinking the Education of Aviation Specialists for a New Era. Russian Engineering Research, 39(3), 268-271.

[7].Zheltenkov, A., Syuzeva, O., Vasilyeva, E., \& Sapozhnikova, E. (2017, October). Development of investment infrastructure as the factor of the increase in investment attractiveness of the region. In IOP Conference Series: Earth and Environmental Science (Vol. 90, No. 1, p. 012122).

[8].Harrisson, D., \& Széll, G. (2009). Social innovation, the social economy and world economic development: democracy and labour rights in an era of globalization (Vol. 17). Peter Lang.

[9].Jacobsen, H., \& Jostmeier, M. (2012). What is social about service innovation? Contributions of research on social innovation to understanding service innovation. In Challenge social innovation (pp. 107-118). Springer, Berlin, Heidelberg.

[10]. Pavlutskiy, A., \& Alekhina, O. (2002). Upravleniye personalom: stereotipy i real'nost'. Upravleniye personalom, (8), 53-55.

[11]. Bell, D., \& Inozemtsev, V. L. (2007). The era of disunity: Reflections on the world of the $21 \mathrm{st}$ century.-M. Center for Post-Industrial Studies, 72.

[12]. Weber, M. (1978). Economy and society: An outline of interpretive sociology (Vol. 1). Univ of California Press.

[13]. Bell, D. (1965). The End of Ideology-on the Exhaustion of Political Ideas in the Fifties: Rev. Ed. Free Press. 

[14]. Popov, R. A., Sekisov, A. N., \& Shipilova, N. A.
The Economics of Innovation in Modern Russia: Practice, Problems and Prospects. International Journal of Economics and Financial Issues, 6(8S), 184-188.

[15]. Komleva, N., Danchenok, L., \& Gulaya, T. (2010). Innovative information environment for enriching education quality. International Journal of Foresight and Innovation Policy, 6(4), 248-257.
[16]. Witkamp, M. J., Raven, R. P., \& Royakkers, L. M. (2011). Strategic niche management of social innovations: the case of social entrepreneurship. Technology Analysis \& Strategic Management, 23(6), 667-681.

[17]. Schultz, T. W. (1971). Investment in human capital. The role of education and of research.

[18]. Mincer, J. (1974). Schooling, Experience, and Earnings. Human Behavior \& Social Institutions No. 2. 